\title{
Preliminary Archaeological Investigations of part of the San Pedro Acequia, San Antonio, Texas
}

Fred Valdez Jr.

Department of Anthropology, The University of Texas at Austin

Jack D. Eaton

Follow this and additional works at: https://scholarworks.sfasu.edu/ita

Part of the American Material Culture Commons, Archaeological Anthropology Commons, Environmental Studies Commons, Other American Studies Commons, Other Arts and Humanities Commons, Other History of Art, Architecture, and Archaeology Commons, and the United States History Commons

Tell us how this article helped you.

This Article is brought to you for free and open access by the Center for Regional Heritage Research at SFA ScholarWorks. It has been accepted for inclusion in Index of Texas Archaeology: Open Access Gray Literature from the Lone Star State by an authorized editor of SFA ScholarWorks. For more information, please contact cdsscholarworks@sfasu.edu. 
Preliminary Archaeological Investigations of part of the San Pedro Acequia, San Antonio, Texas

\section{Creative Commons License}

\section{(c) (1) (8)}

This work is licensed under a Creative Commons Attribution-NonCommercial 4.0 International License 


\title{
PRELIMINARY ARCHAEOLOGICAL INVESTIGATIONS \\ OF PART OF THE SAN PEDRO ACEQUIA, SAN ANTONIO, TEXAS
}

\author{
Fred Valdez, Jr. \\ and \\ Jack D. Eaton
}

\section{Report Submitted to}

General Services Administration

Center for Archaeological Research The University of Texas at San Antonio Archaeological Survey Report, No. 85 


\title{
PRELIMINARY ARCHAEOLOGICAL INVESTIGATIONS \\ OF PART OF THE SAN PEDRO ACEQUIA, SAN ANTONIO, TEXAS
}

\author{
Fred Valdez, Jr. \\ and \\ Jack D. Eaton
}

\author{
Report Submitted to \\ General Services Administration
}

Center for Archaeological Research The University of Texas at San Antonio Archaeological Survey Report, No. 85 
Page

Acknowledgments .................... . $i$...

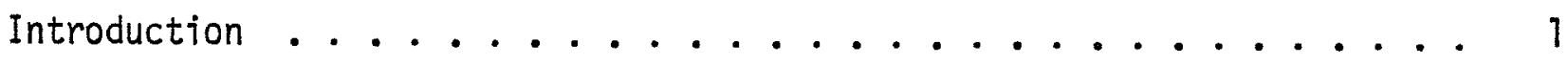

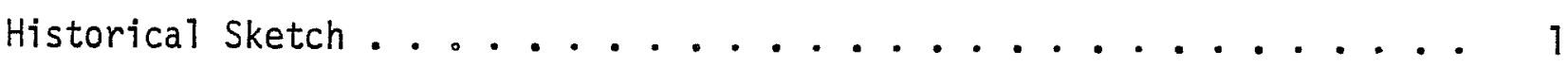
Previous Investigations of San Antonio Acequias . . . . . . . . 3 Current Investigations ................. 3

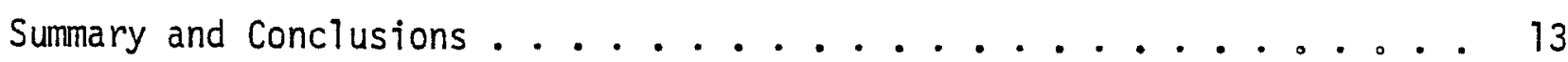

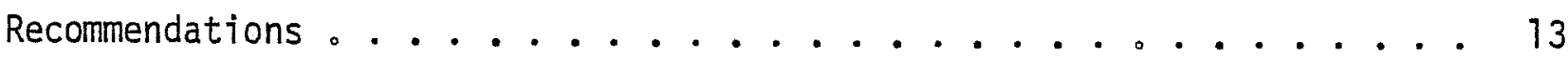
References cited ................ 15

\section{LIST OF FIGURES}

Figure

1. Map of San Pedro Acequia ............... 2

2. Routing of San Pedro Acequia Through GSA Property ........ 5

3. Trench 1 Profile ................ 6

4. Trench 3 Profile ................. 7

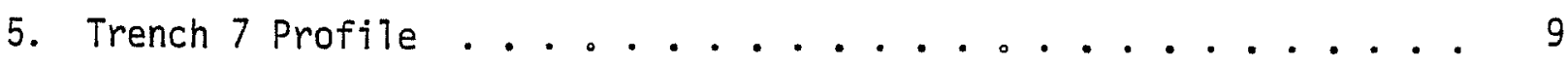

6. Trench 11 Profile....................... 11

7. Trench 12 Profile.................... 12 


\section{ACKNOWLEDGMENTS}

Many people contributed to the success of this project. Thomas R. Hester, Director of the Center for Archaeological Research, served as Principal Investigator. Jack Eaton, Assistant Director of the Center and Co-Principal Investigator, administered the project and provided general supervision. Anne A. Fox provided advice as well as the loan of books from her library for background information.

Patricia Osborne, Dorothea Phillips and General William Harris are thanked for their helpful information and interest in this project. Mike Folgum of Blackie Wright's Backhoe provided skillful excavation of the trenches. James Escobedo assisted with the field work; and Robert Flores with research at the Barker Library in Austin, Texas.

Joan F. Valdez is especially thanked for taking time from a very busy schedule to type the first draft of this report. 
In April 1979, Mr. R. W. Miller, Director of Construction Management, General Services Administration (GSA), contacted the Center for Archaeological Research, The University of Texas at San Antonio, to request archaeological investigations of GSA property located south of the 01d U.S. Arsenal, between South Flores Street and South Main Avenue in downtown San Antonio. The investigations would be conducted to determine if the Spanish Colonial San Pedro Acequia (not to be confused with San Pedro Creek nearby) ran through the property as indicated on old maps; and if so, to locate it and describe its construction and condition. This information was needed so that the Acequia (ditch), if found in the area, could be avoided and protected during planned future developments.

Early in June the Center was authorized to proceed with the investigations, and two archaeologists, with the aid of a backhoe, spent five days systematically testing the property. The Acequia was eventually found, but not precisely where it was indicated to be on available maps. Because time and funding allotted to do the investigations were nearly expended before a stone-lined portion of the Acequia was discovered, the tests were considered incomplete for detailed planning purposes. Therefore, this report will describe what was actually found and recommendations for continued investigations to more fully trace and record the Acequia.

The current project was done under contract between the Center for Archaeological Research, The University of Texas at San Antonio, and the General Services Administration (Mr. Miller, letter dated May 17, 1979). The field work was done by Fred Valdez, Jr., aided by James Escobedo, Technical Staff Assistants, under the supervision of Dr. Thomas R. Hester, Center Director and Jack D. Eaton, Assistant Director.

\section{HISTORICAL SKETCH}

The first significant European settlement of what would eventually become San Antonio consisted of Spanish missionaries and soldiers who arrived at San Pedro Springs in 1718. One of the priorities of the early settlement was to plan and construct a system of acequias (channels) to irrigate farm lands (Castañeda 1936:96). These acequia systems may have expanded from some ditches initfated by a few earlier settlers who were living in the area prior to 1718 (Chabot 1937:91). Although 1ittle is known about which of the several acequias was dug first, it seems likely that, since the first settlement was near the San Pedro Springs (Barnes 1910:93; Crook 1967:97), it was possibly there that the first irrigation ditch was dug. The first ditch being fed by the springs probably became the San Pedro acequia, which ran south through the present downtown area, in front of San Fernando Cathedral, and continued south through the present study area and then on to join the San Antonio River (Fig. 1). Corner (1890:44) notes that the San Pedro acequia "was constructed to supply the Villa Capital de San Fernando as well as to irrigate lands along its course." Corner (1890:105) also contends that the acequia was the principal source of drinking water for the townspeople, while the San Antonio River and San Pedro Creek were reserved for bathing and washing. 


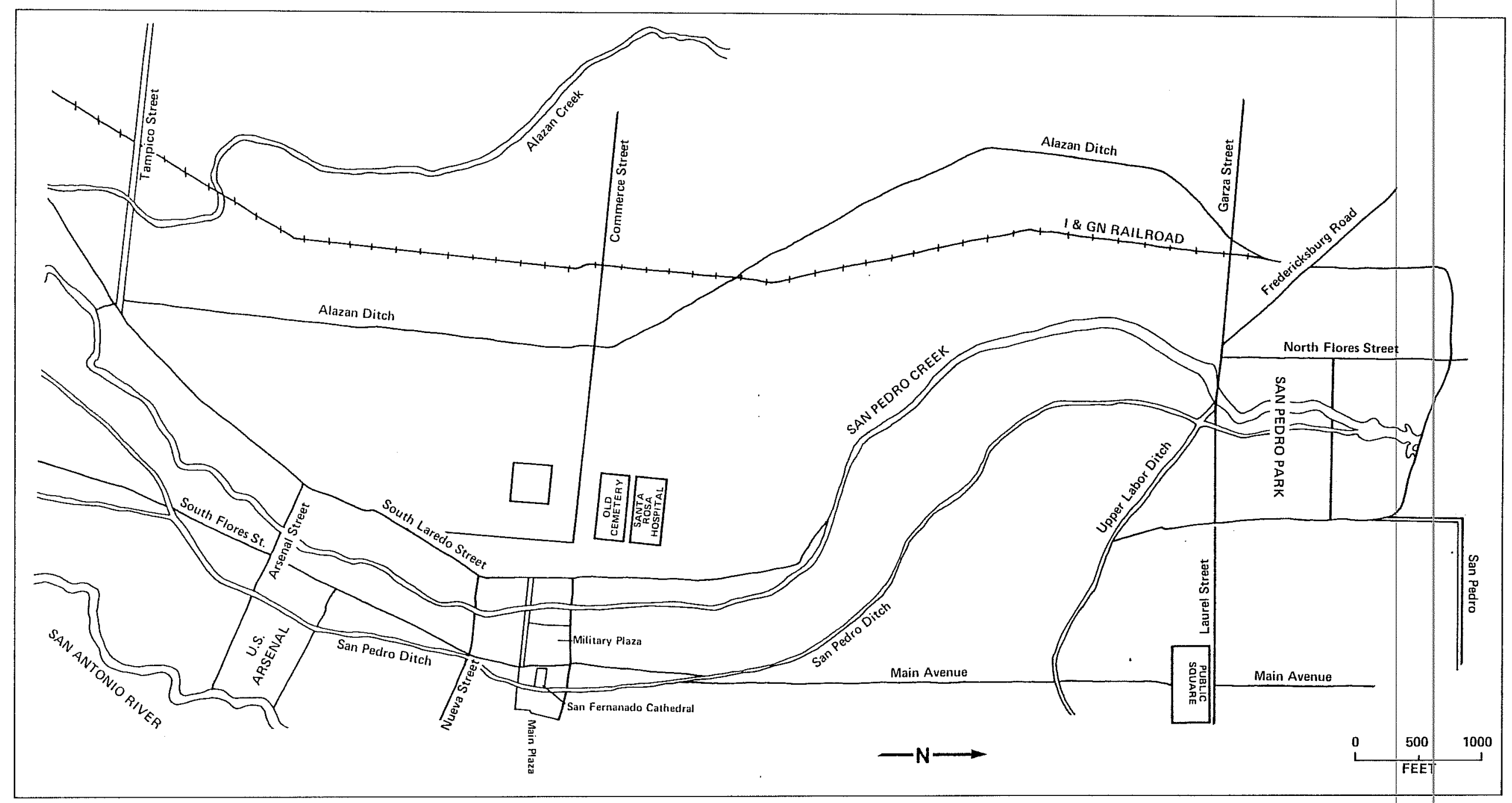

Figure 1. Map of San Pedro Acequia (after Fox 1978:2). 
Originally the acequias were simple linear ditches roughly one meter or so in width and about the same in depth. Much of the acequia system remained simple ditches; however, sections of the San Pedro acequia, which passed through the densely populated areas of the town, eventually were stone-lined.

During the Spanish Colonial period, it was the duty of the local inhabitants to periodically clean and otherwise maintain the acequias as decreed by Spanish law (Fox 1978:1). In the early 19th century, during revolutionary times, the system of use and care of the acequias became inadequate through neglect. This situation improved when Capt。 J.H. Beck became the first American manager of the ditches in 1850 (Corner 1890:50). Then, in 1858, the city of San Antonio took charge of the acequia system (Corner 1890:50; Fox 1978:1).

In 1859, the U.S. Army acquired a large section of land, south of downtown San Antonio, and built an arsenal (Heusinger 1951:27). The San Pedro Acequia crossed through the U.S. Arsenal property and was still open and in operation at that time (Fox 1978:3). The property under investigation in this report is located just south of the U.S. Arsenal site.

As the town population grew, land used for farming was shifted further south, and with the development of wells, cisterns, and a city water supply, the acequias once again fell into disrepair about 1906 (Fox 1978:3). The ditches became garbage dumps, and the eventual filling in of the channels terminated the flow of water. The GSA property under present investigation was at one time a residential area, and as a result of growth and developments, part of the San Pedro Acequia that ran through these lots was filled in and covered over. At the present time the property is a large park area.

\section{PREVIOUS INVESTIGATIONS OF THE SAN ANTONIO ACEQUIAS}

Archaeological investigations of parts of the San Antonio Acequia system have been undertaken in the past by various archaeologists. Schuetz (1970) examined a segment of Acequia Madre at Hemisfair Plaza; Hester (Adams and Hester 1973) tested a section of the Alamo Madre Acequia on Alamo grounds behind the souvenir shop; Sorrow (1972) excavated a part of the same Acequia just north of the Daughters of the Republic of Texas (DRT) Library; Fox (1978a) uncovered segments of the San Pedro Acequia at the 01d Arsenal, and also at the County Courthouse Annex site (Fox 1978b). In addition, Katz (1978) reported uncovering an uni ined ditch as a possible acequia near Hemisfair.

\section{CURRENT INVESTIGATIONS}

In early June 1979, archaeologists from the Center for Archaeological Research began backhoe trenching in search of the San Pedro Acequia expected to lie south of the U.S. Arsenal where a GSA motor pool is planned. The trenching was in the area bordered by S. Flores St., Sheridan St., S. Main Ave。, and W. Johnson St. The zone south of Johnson St. was not tested because of concrete paving and parked cars. The basic goals of the project were to locate the acequia and to record its construction and present condition. The search for the acequia was based upon a sketch map provided by GSA. 
During the testing, 13-backhoe trenches were dug in select places on the prop erty and the soil profiles recorded. These tests, which will be briefly described, located two small sections of a stone-lined acequia and two sections of a simple uniined ditch which may be part of the acequia system. In addition, other trenches were dug in intermediate areas which failed to locate the acequia as indicated on the GSA map. The exploratory trenches are numbered in order of excavation as shown in Fig. 2.

\section{Trench 1}

This trench was dug parallel to Sheridan Street where the San Pedro Acequia was estimated to enter the GSA property from the north. The trench, which began $29.5 \mathrm{~m}$ west of the corner of Sheridan and S. Main, was about $30 \mathrm{~m}$ in length and $1 \mathrm{~m}$ in width. The soil stratigraphy consisted of around $30 \mathrm{~cm}$ of black alluvium topsoil followed by $60 \mathrm{~cm}$ of brown clay loam. Below this was $50 \mathrm{~cm}$ of brown sandy loam which lay upon basal caliche.

The distinctive profile of a shallow ditch, beginning near the surface and extending $1.3 \mathrm{~m}$ down to caliche base, was noted (Fig. 3 ). Within the ditch silt fill were procelain tile fragments, some rusted metal pieces, a log fragment and charcoal stains. Possibly this ditch is an unlined portion of the San Pedro Acequia or a feeder channel.

\section{Trench 2}

This trench, which was nearly $30 \mathrm{~m}$ in length, was dug close to and parallel with W. Johnson Street. Here the black topsoil was $40 \mathrm{~cm}$ in depth covering $30 \mathrm{~cm}$ of dark brown clay loam, and below was $20 \mathrm{~cm}$ of brown sandy loam. This lay upon caliche at $90 \mathrm{~cm}$ below the surface. No indication of a ditch was found here.

\section{Trench 3}

This trench was located $9.5 \mathrm{~m}$ south of Trench 1 and was $8.5 \mathrm{~m}$ long. Here the soil stratigraphy was the same as Trench 1 except for some differences in actual soil depths.

As in Trench 1 the profile of a ditch was noted in the cut (Fig. 4). Materials recovered from the ditch fill include: a fragment of cut 7 imestone, several yellow bricks, fragments of a sewer pipe, a green wine bottle, small jar, longnecked bottle, porcelain pottery sherds, clay tiles, wire nail, and several bison or cow bones.

\section{Trenches 4,5 and 6}

These three trenches were placed near Johnson Street east of Trench 2 and in series-parallel configuration as shown in Fig. 2. Each was about $22 \mathrm{~m}$ in length. Trench 4 uncovered some concrete block fragments which might have been remains of a house foundation. The other two trenches had nothing unusual in the soil 


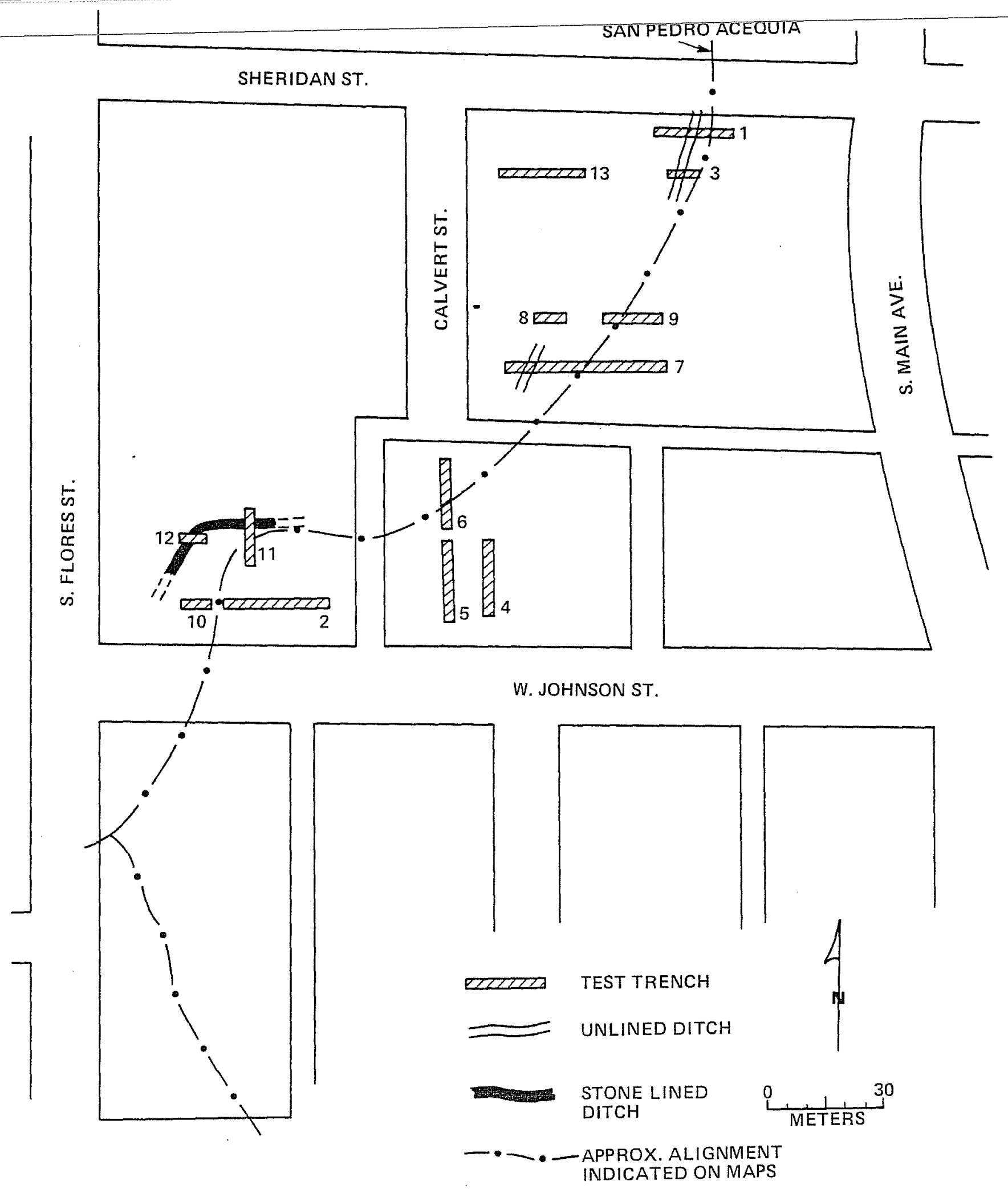

Figure 2. Routing of San Pedro Acequia Through GSA Property. Shown is the estimated routing, the locations of the test trenches, and where sections of the actual lined and unlined ditches were found. 
TRENCH 1 SOUTH PROFILE
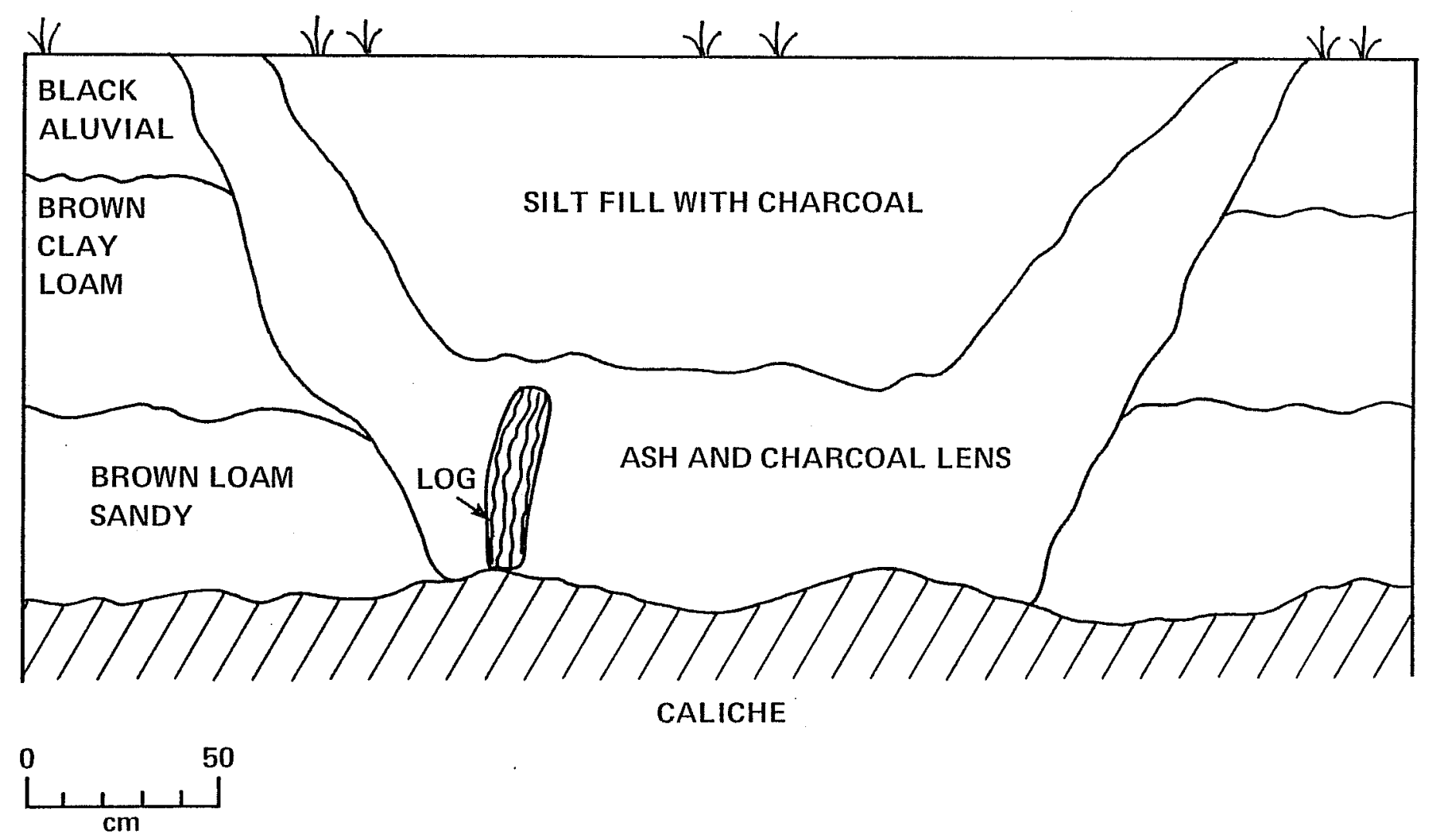

Figure 3. Trench 1 profile. A portion of the profile showing the cross-section of an untined ditch. 


\section{TRENCH 3 SOUTH PROFILE}
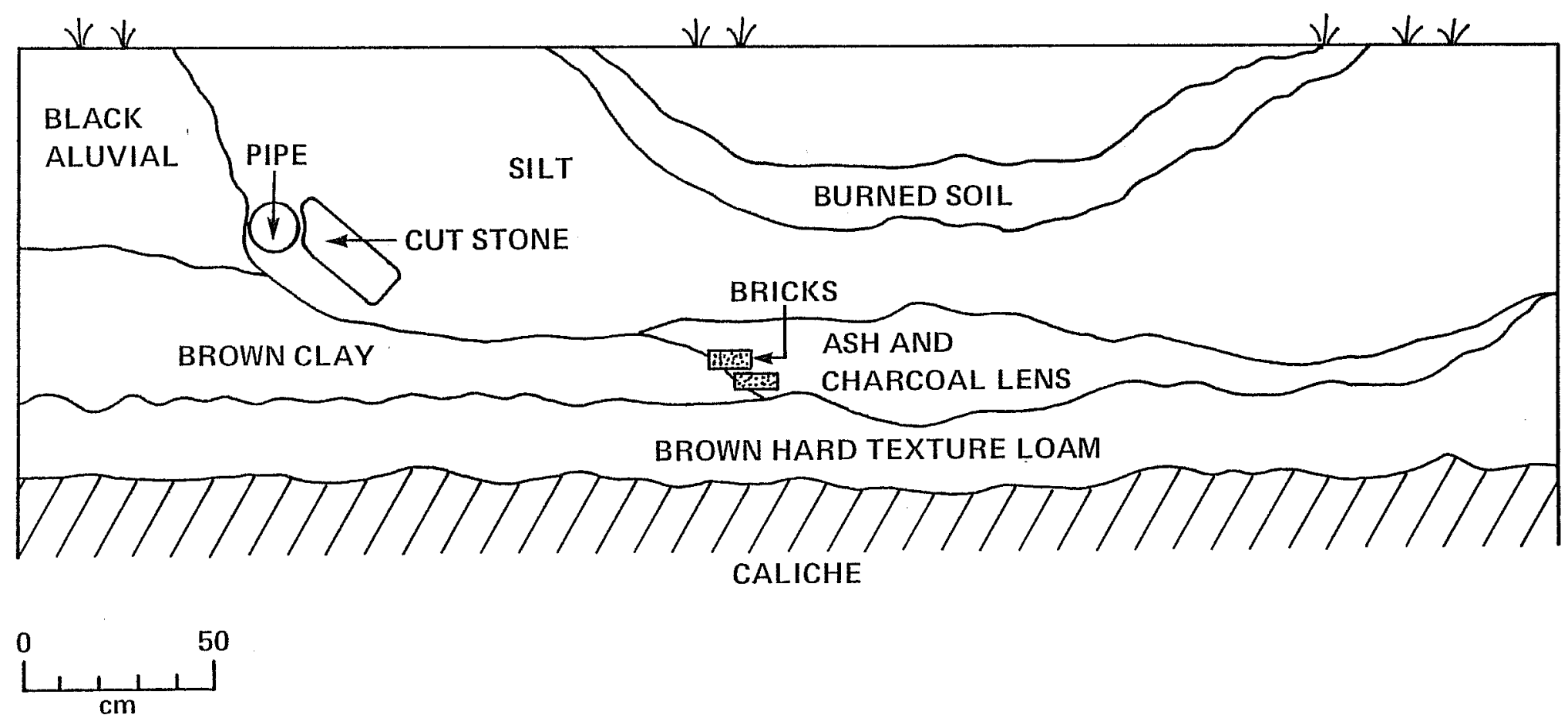

Figure 4. Thench 3 Profile. Portion of the trench profile showing a cross-section of an unlined ditch. 
profiles. The soil stratigraphy here consisted of $20-30 \mathrm{~cm}$ of gravel with some brick fragments on the surface. Below this was $20-30 \mathrm{~cm}$ of black clay, $40 \mathrm{~cm}$ of dark brown clay, and $20 \mathrm{~cm}$ of light brown soil with caliche mixed in. This rested upon basal caliche. Although the GSA map indicated the acequia to run through this zone, no trace of it was noted in the soil cuts.

\section{Trench 7}

This trench began $10 \mathrm{~m}$ east of Calvert Street and extended east for $45 \mathrm{~m}$ (Fig. 2). The soil stratigraphy consisted of $20 \mathrm{~cm}$ of black alluvium topsoil followed by $10-60 \mathrm{~cm}$ of dark brown clay loam. Below lay $30 \mathrm{~cm}$ of yellowish-tan clay loam which covered basal caliche.

In the eastern area of the trench the excavations uncovered structural materials similar to the possible foundation debris noted in Trench 4 . This seems to indicate the site of a previous building.

The western part of the trench displayed the profile of a ditch much like that described for Trenches 1 and 3 (Fig. 5). Possibly this represents part of the acequia system. Materials recovered from the filled-in ditch included: fragments of bison or cow bones, a green bottle, fragments of two blue bottles, porcelain fragments, the handle of a cut glass pitcher, a rusted metal key, and fragments of leather shoe soles.

Trenches 8 and 9

These two trenches were spaced just north of Trench 7 as shown in Fig. 2 . Trench 8 was dug to uncover another section of the ditch to verify its routing. However, no trace of the ditch was noted. Trench 9 was placed to see if structural materials, or possibly the ditch, would be found as in Trench 7 . This test was also negative. The basic soil stratigraphy is the same as described for Trench 7 .

\section{Trench 10}

This trench was placed immediately west of, and in line with, Trench 2 . The purpose was to extend the testing in that area in search of the acequia. It was not found here.

The soil stratigraphy for Trench 10 differed somewhat from that just to the east. In the eastern part of the trench the topsoil was a gray-brown clay about $110 \mathrm{~cm}$ in depth. Below this was $40 \mathrm{~cm}$ of brown clay loam which graded into caliche gravels. The west side of the trench displayed dark brown topsoil overlaying large grain sand down to basal caliche. This appears to have been much disturbed in the past and no evidence of the acequia was found. 
TRENCH 7 NORTH PROFILE
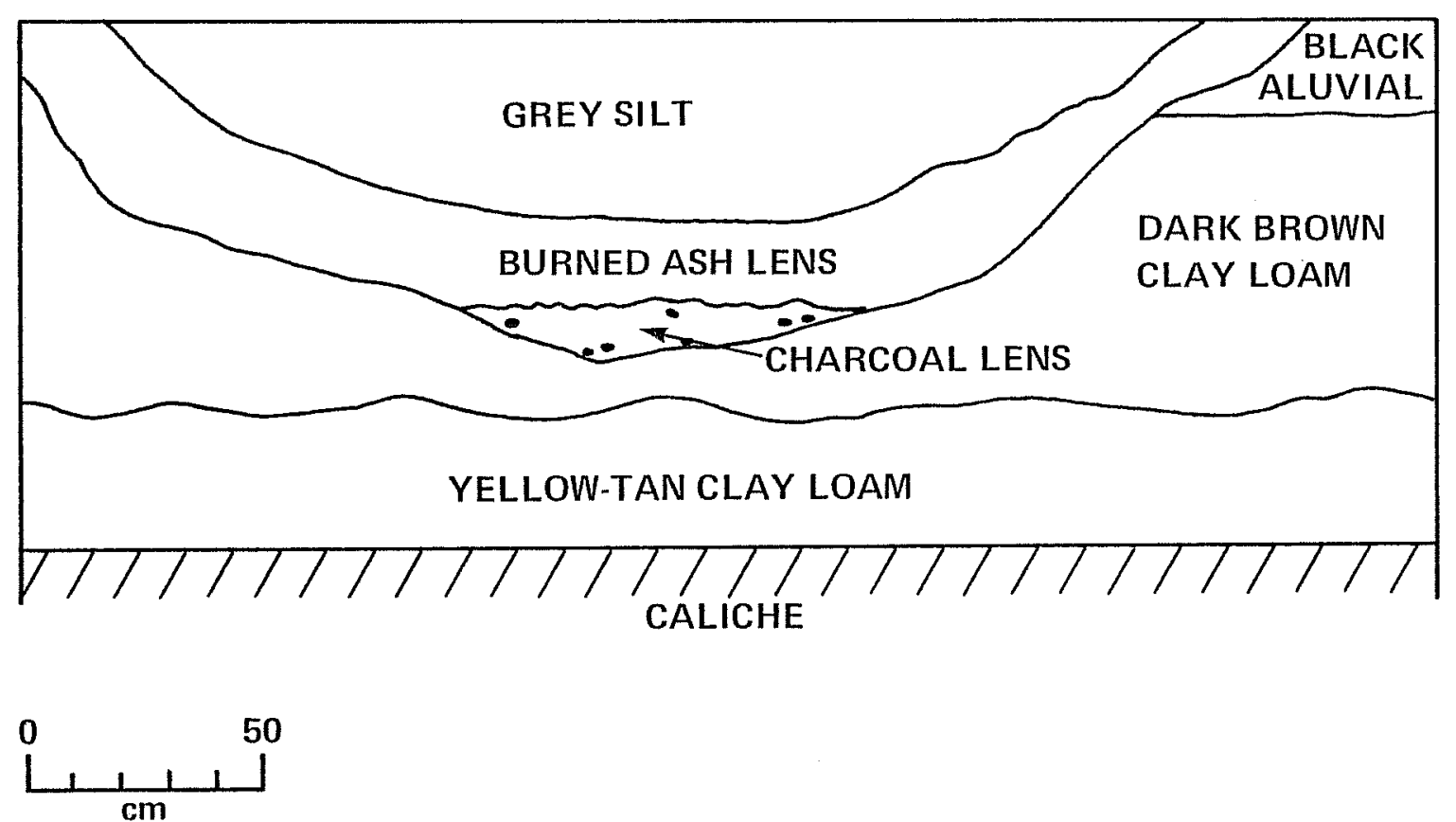

Figure 5. Thench 7 Profile. Portion of the profile showing a cross-section of an unlined ditch. 
Trench 11

This trench was located $10 \mathrm{~m}$ north of Trench 2 and was cut in the $\mathrm{N}-\mathrm{S}$ axis across a section of asphalt paving (Fig. 2). With the removal of the paving, two parallel lines of cut stones extending in the E-W direction were exposed and immediately identified as the stone-lined San Pedro Acequia. The acequia was filled with silt and cultural debris.

The walls of the acequia, which were found just below the paving, are each 50$55 \mathrm{~cm}$ in thickness, spaced $90 \mathrm{~cm}$ apart, and are vertical to a depth of one meter to the unlined bottom (Fig. 6). The walls of the acequia are built of cut limestone blocks with dressed faces set in pink colored, sandy lime mortar. Chinking is used to fill spaces and to help set the stones which rest upon basal caliche.

The interior of the acequia is filled to a depth of around $85 \mathrm{~cm}$. At the bottom, and laying upon basal caliche, is $15 \mathrm{~cm}$ of dark gray clay. Within the silt are fragments of charcoal and limestone blocks, and a variety of other cultural debris. Materials collected include: a Coca Cola bottle, a Tejas bottle, two brown colored bitterroot bottles, a green glass flask, a small blue glass jar, a long-necked green bottle, a long-necked clear glass bottle, porcelain and crockery potsherds, an unidentified circular glass object, hackberry seeds, an automobile spark plug, and a 1949 Texas license plate. Also found was a brass hilt of a small dress sword.

\section{Trench 12}

Located $16 \mathrm{~m}$ north of Trench 10 , and $13 \mathrm{~m}$ west of Trench 2, this trench was placed to test the presence and condition of the acequia where it appeared to turn south as indicated by surface ridging. A section of the stone-lined acequia was uncovered which appears to angle toward the corner of S. Flores St. and W. Johnson St. (Fig. 2). The construction of the acequia is the same as described for Trench 11. However, the stone wal1s at this location were covered by around $20 \mathrm{~cm}$ of dark topsoil and rests upon about $30 \mathrm{~cm}$ of dark clay loam instead of basal caliche (Fig. 7). Within the acequia is $45-50 \mathrm{~cm}$ of loose grainy silt. Below this is $10-20 \mathrm{~cm}$ of sandy silt with lenses of snail shells overlaying $30 \mathrm{~cm}$ of dark gray clay. Below is $30 \mathrm{~cm}$ of brown clay loam which rests upon basal caliche.

Cultural materials collected from the acequia in this section include: the neck of a brown glass bottle, a wooden knife handle, a small white glass jar, a metal can key, bison or cow bones, and oyster she11s.

\section{Trench 13}

This trench was dug to the west of Trench 3, near the corner of Sheridan St. and Calvert St., to see if possibly the stone-lined acequia ran parallel with the plain ditch discovered in Trenches 1 and 3. Nothing was found. Soil deposition here consists of four distinct zones. Topsoil is $40 \mathrm{~cm}$ of black alluvium followed by $30 \mathrm{~cm}$ of dark brown clay. Below this is $20 \mathrm{~cm}$ of brown sandy loam with 
SAN PEDRO ACEQUIA

TRENCH 11

EAST PROFILE
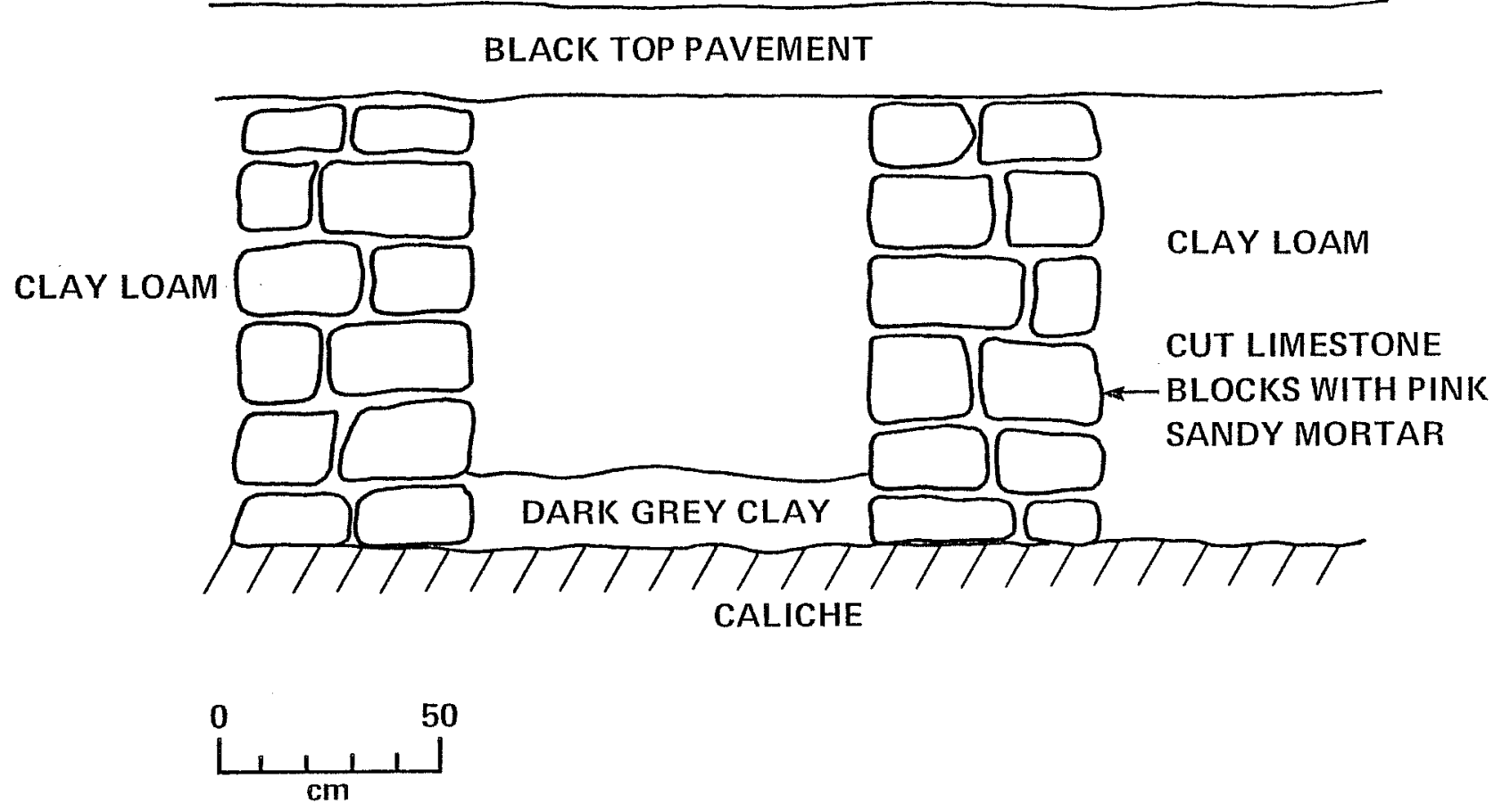

Figure 6. Trench 11 Profile. Portion of the trench profile showing cross-section of the stone-lined ditch. 
SAN PEDRO ACEQUIA

TRENCH 12

SOUTH PROFILE
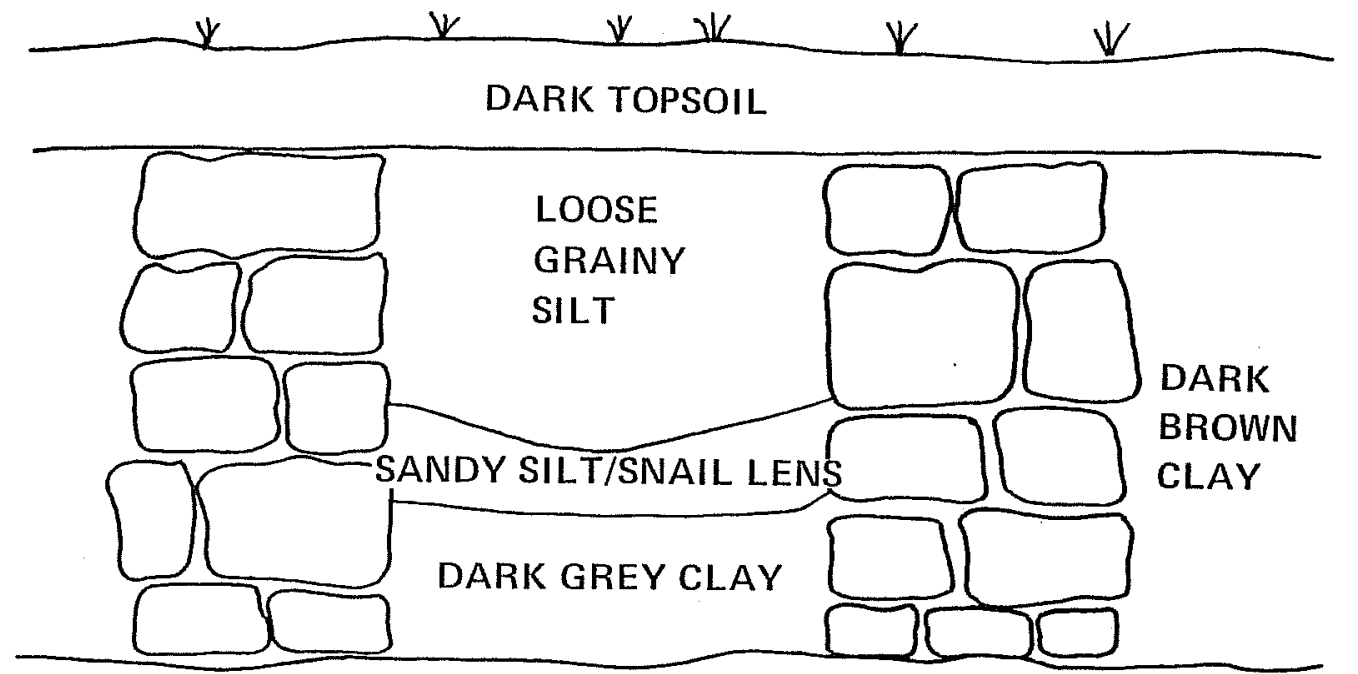

BROWN CLAY LOAM
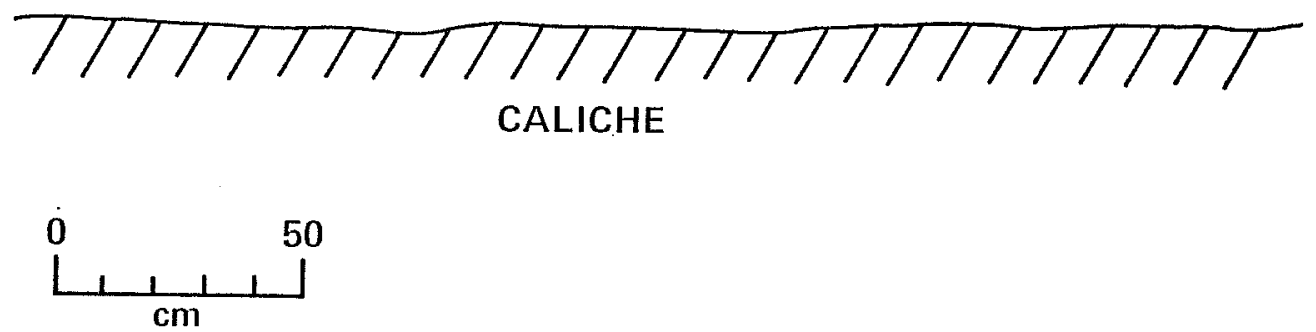

Figure 7. Trench 12 Profile. Shown is the cross-section of the stone-7ined ditch. 
pockets of catiche. This rests upon basal caliche. ivo culturai materiai was found.

\section{SUMMARY AND CONCLUSIONS}

The test excavations conducted to locate the San Pedro Acequia consisted of 13 backhoe trenches of varying lengths dug in selected places in the study area. The selection for the placement of the trenches was based upon a marked-up map supplied by the GSA, and certain other available maps, which indicated the approximate routing of the acequia through GSA property. The locations of the trenches are shown in Fig. 2.

Trenches 2, 4-6, 8-10, and 13 gave no indication of the acequia. General1y, these trenches represented culturally sterile areas and contributed by noting where the acequia does not occur.

Trenches $1,3,7,11$ and 12 encountered 7 ined and unlined ditches. The stonelined ditch is bel jeved to be the San Pedro Acequia main channel; however, it is not certain at this time if the sections of unlined ditch to the east are also parts of the main channel or represent a parallel or lateral channel.

Although the sections of the acequia uncovered, both lined and unlined, were not found exactly where indicated on the maps, they are close enough to identify with the map routing. A problem with the identification of the unlined portion of the acequia on the northeastern side of the property with the stonelined portion on the west side, lies with the apparent absence of a connecting portion noted in the intermediate area trenching. This may be a sampling problem since the trenches were placed where the acequia was expected to be, but not found. It is possible that the actual acequia routing is very close to or beneath Calvert Street. It appears that on the west side of Calvert Street the acequia is stone-lined, while on the east side it is not. Possibly these differences are related to past settlement and developments in the area.

\section{RECOMMENDATIONS}

The testing described in this report has uncovered what appear to be two separate portions of the San Pedro Acequia, and each was found approximately where indicated on available maps. The western portion is a formally constructed stone-lined channel as expected for this important historic landmark. However, the eastern portion appears to be a simple unlined ditch of about the same size and depth but not formal in appearance. Limited trenching between the two areas did: not locate a connection between the formal and informal channels. This might indicate that these are two separate channels; for example the main channel and a lateral. It might also suggest that the routing of the acequia in the intermediate area (bisected by Calvert St.) differs sufficiently from the maps to have been missed by the trenching, and that part of the acequia was lined while other parts were not. Possibly this was due to local developments.

The full identification and exact routing of the acequia in the study area, and if we are confronted with a single channel or a split one, remains essentially 
unanswered. Because time and funding for the present study were not sufficjent to adequately test a complicated situation, the following recommendations for further work are provided:

1. The uncovered stone-lined portion of the acequia on the western side of the property appeared to angle southwest toward the corner of S. Flores St. and W. Johnson St. To the east, the acequia heads toward Calvert St., possibly angling to the northeast to join the unlined ditch. This entire section of the acequia should be uncovered sufficiently to record the exact routing and where it joins the streets. The construction of the formal channel should be completely documented. In addition, selective sampling of the interior and exterior of the channel should be made to collect diagnostic artifacts. This cultural debris would be useful as an aid in determining the construction date of the stonework and provide valuable insight into our cultural past.

2. The unlined portion of the acequia should be followed by more extensive excavations to record its exact routing and physical description. Adequate testing should be done to note precisely, if possible, where and how it connects, or is otherwise associated with the lined channel to the west. Sampling of the ditch interior should be done to collect diagnostic artifacts.

3. Test excavations should be conducted in the southern portion of the properties which were not undertaken previously because of hard surface paving and parked cars. The areas to be tested should be designated non-parking and available for mechanical digging operations. In the event that it proves to be impractical to remove the surface at this time, provisions should be made for an archaeologist to monitor removal of the surface by others at some future time and to adequately record any remains of the acequia which may lie beneath.

The planned end result of the above recommended work would be the accurate mapping of the acequia routing through the properties to be developed, the recording of the condition and construction of the acequia along its entire length through the study area, the documentation and interpretation of collected cultural materials, and to provide suggestions for the protection of the acequia or portions of it as required. 
Adams, R. E. W. and To Ro Hester

1973 Letter to Dr. Fred Wendorf, Chairman, Texas Antiquities Committee, concerning completion of excavations at Mission San Antonio de Valero, November 26 .

Arneson, E。 P。

1921. Early Irrigation in Texas. Southwestern Historical Quarterly $X X V: 121-130$ 。

Barnes, C. M.

1910 Combats and Conquests of Immortal Heroes. Guessaz and Ferlet, San Antonio.

Castanedo, C. E.

1936 The Mission Era: The Winning of Texas, 1694-1730. Our Catholic Heritage in Texas Vo1. II. Von Boeckman-Jones Company, Austin.

Chabot, F。E。

1937 With the Makers of San Antonio. Artes Graficas Press, San Antonio。

Corner, W.

1890 San Antonio de Bexar. Bainbridge and Corner, San Antonio.

Crook, C. E。

1967 San Pedro Springs Park, Texas oed Recreation Area. Private printing, San Antonio.

Fox, A。A.

1978a Archaeological Investigations of Portions of the San Pedro and Alazan Acequias in San Antonio, Texas. Center for Archaeological Research, The University of Texas at San Antonio, Archaeological Survey Report 49.

1978b Preliminary Archaeological Assessment of South Parking Lot Area (Phase I) Site of Courthouse Annex, San Antonio, Texas. Letter report to Bexar County Commissioners' Court.

Heusinger, E。 $W_{0}$

1951 A Chronology of Events in San Antonio. Standard Printing Company, San Antonio. 
Holmes, $W_{0} H_{0}$

1962 The Acequias of San Antonio. Masters Thesis, St. Mary's University, San Antonio, Texas.

Katz, P. R.

1978 Archaeological and Historical Investigations in the Arciniega Street Area, Downtown San Antonio. Texas. Center for Archaeological Research, The University of Texas at San Antonio, Archaeological Survey Report 61.

Minor, J. E. and M. L. Steinberg

1968 A Brief on the Acequias of San Antonio. The San Antonio Branch of the Texas Section, American Society of Civil. Engineers.

Schuetz, M. K。

1970 Excavation of a Section of the Acequia Madre in Bexar County, Texas, and Archaeological Investigations at Mission San Jose in Apri1 1968. Texas Historical Survey Committee, Archaeological Report 19.

Sorrow, W. M.

1972 Archeological Salvage Excavations at the Alamo (Mission San Antonio de Valero) 1970. Texas Archeological Salvage Project, Research Report 4. 